\title{
Susceptibility of Ponderosa Pine to Endocronartium harknessii and Other Causes of Mortality in Pennsylvania
}

\author{
A. F. Egan, Assistant Professor, Division of Forestry, West Virginia University, Morgantown 26506-6125; and \\ W. Merrill, Professor of Plant Pathology, The Pennsylvania State University, 211 Buckhout Lab, University Park \\ 16802
}

\begin{abstract}
Egan, A. F., and Merrill, W. 1997. Susceptibility of ponderosa pine to Endocronartium harknessii and other causes of mortality in Pennsylvania. Plant Dis. 81:1173-1176.

The effects of Endocronartium harknessii on provenances of Pinus ponderosa planted in 1969 on a coal strip-mine spoil bank in central Pennsylvania were reassessed. In 1982 infection levels among seed sources ranged from 4.9 to $52.5 \%$. In 1991 infection levels ranged from 29 to $95 \%$, and mortality due to rust infection ranged from 9 to $58 \%$ among these seed sources. Levels of infection, mortality due to rust infection, and mortality unrelated to rust infection differed significantly among seed sources $(P<0.001,<0.001$, and $=0.023$, respectively). Among geographic ecotypes, there were no significant differences among percentages of trees infected $(P=$ $0.094)$, but there were significant differences among trees surviving outplanting $(P=0.007)$, mortality due to rust $(P=0.004)$, and mortality unrelated to rust $(P<0.001)$. Only one provenance incurred less than $40 \%$ infection, indicating that virtually none of these types of provenances are suitable for reforestation in areas of eastern North America where E. harknessii occurs.
\end{abstract}

In 1969 the U.S. Forest Service established a provenance study in central Pennsylvania to evaluate the suitability of 49 seed sources of Pinus ponderosa Laws. for reforestation of coal strip-mine spoil banks (2). The plantation was established on a spoil bank in Clearfield County, PA, consisting of black calcareous shale sloping gently to the south. The seedlings used were left over from a provenance study established in Michigan 1 year before $(2,9)$, creating variation in number of replications among sources. The original planting consisted of randomized blocks containing 10 or 11 seedlings of each seed source, each replicated six times, except sources 862 (seven replications); 814, 837, and 843 (five replications); 720, 822, and 856 (four replications); and 823 and 832 (two replications). The seedlings had been grown at Bessey Nursery, Halsey, NE, and transplanted twice prior to outplanting. The elevation, latitude, longitude, and geographic ecotype of each provenance are listed by Davidson (2), and approximate source locations were mapped by Merrill et al. (5). Six years after outplanting, survival and height growth of seedlings were recorded, and based on these measurements, 11 seed sources were

Corresponding author: W. Merrill

E-mail: wxm1@psu.edu

Contribution 1927, Department of Plant Pathology, The Pennsylvania Agricultural Experiment Station.

Accepted for publication 8 July 1997.

Publication no. D-1997-0804-02R

(C) 1997 The American Phytopathological Society recommended as "superior" for reforesting bituminous spoil banks (2). Rust infection that existed at the time either was not recognized or was ignored.

Some seedlings were infected in the seedbed or transplant bed by the autoecious fungus Endocronartium harknessii (J.P. Moore) Y. Hiratsuka, which causes pine-pine gall rust, and were outplanted (4,5). By 1982 the pathogen had become well established throughout the plantation, and the susceptibility of the various seed sources to the pathogen was evaluated (5). Since 1982 rust incidence has increased dramatically and caused substantial mortality in some seed sources. Mortality of uninfected trees also has occurred. Therefore, during the fall of 1991 the effects of this pathogen on these ponderosa pine provenances were reevaluated.

\section{MATERIALS AND METHODS}

Each tree was examined and placed in one of eight categories: 1 = alive and noninfected; 2 = alive and infected, $<25$ galls; $3=$ alive and infected, 25 to 50 galls; $4=$ alive and infected, $>50$ galls; $5=$ dead due to rust infection; $6=$ dead, cause indeterminate; $7=$ dead, uninfected; and $8=$ missing. Some categories were later combined to facilitate analyses. The KruskalWallis chi-square multiple comparison nonparametric test was used to detect differences among the average frequencies in each category in relation to seed source, geographic ecotypes, and blocks.

When lateral shoots are infected, shoot growth the following year frequently is stunted, probably due to disrupted translocation. During the second year after infec- tion, most of these stunted shoots die. Thus, a high incidence of infection in susceptible trees causes progressive crown deterioration and eventual mortality (4). If more than half the branches on a dead tree bore terminal branch galls or girdling galls on the main stem, mortality was considered to be caused by rust infection. Trees classified as indeterminate were infected but bore no main stem galls and less than half of the branches had terminal galls. Based on 25 years of research on E. harknessii in the northeastern United States, such trees died from some factor(s) other than rust infection.

\section{RESULTS AND DISCUSSION}

Provenance effects. In 19824.9 to $52.5 \%$ of the trees from the various seed sources were infected (5). By 1991 the proportion of rust-infected trees, both living and dead, ranged from 29 to $95 \%$ (Table 1, column 7), and differences among seed sources were significant $(P<0.001)$. Ten of eleven provenances recommended by Davidson (2) as superior for reforesting spoil banks contained more than $63 \%$ infected trees (Table 1 , column 7). Based on these results, although some of these provenances undoubtedly might be useful in selection or breeding trials, none is superior for reforestation plantings in any eastern area where E. harknessii is known to occur. However, because the pathogen appears to spread via wind only limited distances from infected trees (6), many of these provenances might be useful if the plantation could be established from rust-free seedlings in an area free of the pathogen.

Tree mortality due to pine-pine gall rust ranged from 9 to $58 \%$ and varied significantly $(P<0.001)$ among the seed sources (Table 1, column 2). Two provenances, 833 and 861 , showed no evidence of mortality due to agents other than E. harknessii (Table 1 , columns 3 and 4).

The percentages of dead uninfected trees differed significantly $(P=0.023)$ among provenances (Table 1, column 3 ). We were unable to ascertain the cause(s) of this mortality. There was no evidence of root rots, and although some trees bore evidence of attack by one or more of the pine shoot moths or the pitch nodule maker, Petrova albicapitana, their incidence was insufficient to cause the observed mortality. Adjacent plantings of Larix decidua and $\mathrm{Pi}$ nus resinosa did not incur mortality. 
The percentages of trees per provenance that survived outplanting and were still living in 1991 ranged from 29 to $88 \%$ and differed significantly $(P<0.001)$ among seed sources (Table 1, column 8). Four of the five seed sources with the best survival rates, $839,838,827$, and 837, originated in the Black Hills-high plains area. These five seed sources also had $17 \%$ or less mortality due to pine-pine gall rust (Table 1, column 2).
The high incidence of rust infection is consistent with Merrill and Wenner's (4) finding that gall incidence in $P$. sylvestris Christmas trees increased logistically for several years after infection. They reported more than 17,000 galls on a single $2.5-\mathrm{m}$ Scots pine. Baxter (1) similarly reported more than 18,000 galls on a $3-\mathrm{m}$ Scots pine in Oneida County, NY. The development of this disease in forest plantations bears no resemblance to development of diseases caused by the heteroecious Cronartium spp. As in any autoecious rust, once the pathogen begins to sporulate on an infected plant many of the spores reinfect the same plant, causing massive galling, almost exclusively on the lateral branches, and leading to extensive crown mortality (4). As crown mortality progresses up the stem, height and diameter growth of the infected tree is re-

Table 1. The number of trees in the original planting of ponderosa pine trees in central Pennsylvania, by provenance and ecotype, that survived outplanting and the percentages of those trees that in 1991 were alive, infected or uninfected, or dead due to infection by Endocronartium harknessii or other causes

\begin{tabular}{|c|c|c|c|c|c|c|c|c|c|}
\hline \multirow[b]{2}{*}{ Provenance } & \multirow[b]{2}{*}{ Ecotype $^{a}$} & \multirow{2}{*}{$\begin{array}{c}\text { Number } \\
\text { surviving } \\
\text { outplanting } \\
\text { (Col. 1) }\end{array}$} & \multicolumn{3}{|c|}{$\%$ Dead in $1991^{b}$} & \multicolumn{2}{|c|}{$\%$ Alive in $1991^{b}$} & \multirow{2}{*}{$\begin{array}{c}\text { \% Dead and } \\
\text { living trees } \\
\text { infected } \\
(\text { Col. } 7)\end{array}$} & \multirow{2}{*}{$\begin{array}{l}\text { \% Trees surviv- } \\
\text { ing outplanting } \\
\text { living in } 1991 \\
\text { (Col. 8) }\end{array}$} \\
\hline & & & $\begin{array}{l}\text { Due to rust } \\
\text { (Col. 2) }\end{array}$ & $\begin{array}{c}\text { Uninfected } \\
\text { (Col. 3) }\end{array}$ & $\begin{array}{l}\text { Indeterminate } \\
\text { (Col. 4) }\end{array}$ & $\begin{array}{l}\text { Infected } \\
\text { (Col. 5) }\end{array}$ & $\begin{array}{l}\text { Uninfected } \\
\text { (Col. 6) }\end{array}$ & & \\
\hline 839 & BH & 33 & 9 & 0 & 3 & 58 & 30 & 70 & 88 \\
\hline 838 & $\mathrm{BH}$ & 44 & 14 & 2 & 0 & 52 & 32 & 68 & 84 \\
\hline 856 & ELE & 10 & 10 & 10 & 0 & 50 & 30 & 60 & 80 \\
\hline $827^{\mathrm{d}}$ & HP & 42 & 10 & 10 & 2 & 17 & 62 & 29 & 79 \\
\hline $837^{d}$ & $\mathrm{BH}$ & 46 & 17 & 7 & 0 & 61 & 15 & 78 & 76 \\
\hline 831 & CR & 38 & 16 & 6 & 0 & 54 & 24 & 70 & 78 \\
\hline $704^{\mathrm{d}}$ & HP & 54 & 17 & 4 & 7 & 44 & 28 & 69 & 72 \\
\hline $835^{\mathrm{d}}$ & BH & 39 & 26 & 0 & 3 & 49 & 23 & 77 & 72 \\
\hline 760 & $\mathrm{CR}$ & 42 & 10 & 7 & 6 & 52 & 19 & 71 & 71 \\
\hline 854 & HP & 27 & 22 & 7 & 0 & 33 & 37 & 56 & 70 \\
\hline 824 & HP & 36 & 33 & 3 & 0 & 42 & 22 & 75 & 70 \\
\hline 830 & CR & 30 & 30 & 0 & 3 & 60 & 7 & 95 & 67 \\
\hline 860 & $\mathrm{CP}$ & 14 & 29 & 7 & 0 & 50 & 14 & 79 & 64 \\
\hline 848 & CR & 40 & 30 & 5 & 2 & 45 & 18 & 78 & 62 \\
\hline $814^{\mathrm{d}}$ & $\mathrm{CM}$ & 42 & 17 & 14 & 7 & 40 & 21 & 64 & 62 \\
\hline $832^{d}$ & HP & 16 & 25 & 14 & 0 & 44 & 18 & 69 & 62 \\
\hline 853 & HP & 24 & 17 & 17 & 4 & 21 & 42 & 42 & 62 \\
\hline $834^{\mathrm{d}}$ & $\mathrm{BH}$ & 44 & 30 & 7 & 2 & 55 & 7 & 86 & 61 \\
\hline 701 & HP & 20 & 25 & 10 & 5 & 55 & 5 & 85 & 60 \\
\hline 822 & $\mathrm{HP}$ & 22 & 27 & 0 & 14 & 45 & 14 & 86 & 59 \\
\hline 833 & $\mathrm{BH}$ & 36 & 42 & 0 & 0 & 39 & 19 & 81 & 56 \\
\hline 702 & HP & 39 & 33 & 8 & 5 & 49 & 5 & 87 & 54 \\
\hline 724 & $\mathrm{CP}$ & 26 & 35 & 12 & 0 & 42 & 12 & 77 & 54 \\
\hline 703 & HP & 43 & 30 & 7 & 7 & 26 & 30 & 63 & 53 \\
\hline $825^{\mathrm{d}}$ & $\mathrm{HP}$ & 50 & 42 & 4 & 2 & 36 & 16 & 80 & 52 \\
\hline 758 & $\mathrm{CP}$ & 29 & 45 & 3 & 0 & 41 & 10 & 86 & 52 \\
\hline 862 & SR & 29 & 45 & 3 & 0 & 31 & 21 & 76 & 52 \\
\hline 761 & CR & 49 & 29 & 10 & 10 & 41 & 10 & 80 & 51 \\
\hline 722 & HP & 39 & 18 & 26 & 5 & 26 & 26 & 49 & 51 \\
\hline $757^{d}$ & ELE & 46 & 30 & 15 & 4 & 28 & 22 & 63 & 50 \\
\hline 723 & HP & 32 & 34 & 6 & 9 & 44 & 6 & 88 & 50 \\
\hline 815 & $\mathrm{CN}$ & 30 & 10 & 27 & 13 & 23 & 27 & 47 & 50 \\
\hline 851 & HP & 18 & 39 & 6 & 8 & 39 & 11 & 83 & 50 \\
\hline 829 & $\mathrm{CM}$ & 29 & 24 & 17 & 10 & 45 & 3 & 79 & 48 \\
\hline 858 & $\mathrm{CP}$ & 29 & 45 & 3 & 3 & 34 & 14 & 83 & 48 \\
\hline 852 & HP & 33 & 42 & 6 & 9 & 30 & 15 & 79 & 45 \\
\hline 812 & $\mathrm{CM}$ & 50 & 40 & 10 & 6 & 38 & 6 & 84 & 44 \\
\hline 754 & $\mathrm{~T}$ & 34 & 38 & 6 & 12 & 32 & 12 & 82 & 44 \\
\hline 836 & BH & 28 & 43 & 7 & 7 & 35 & 7 & 86 & 43 \\
\hline $863^{\mathrm{d}}$ & SR & 36 & 39 & 11 & 8 & 28 & 14 & 75 & 42 \\
\hline 845 & $\mathrm{CR}$ & 36 & 50 & 3 & 6 & 31 & 11 & 86 & 42 \\
\hline 861 & $\mathrm{CP}$ & 43 & 58 & 0 & 0 & 35 & 7 & 93 & 42 \\
\hline 763 & CR & 51 & 45 & 6 & 8 & 29 & 12 & 82 & 41 \\
\hline 813 & $\mathrm{CM}$ & 48 & 23 & 25 & 12 & 38 & 2 & 73 & 40 \\
\hline 759 & $\mathrm{CP}$ & 36 & 56 & 3 & 2 & 28 & 11 & 86 & 39 \\
\hline 847 & CR & 36 & 58 & 3 & 0 & 25 & 14 & 83 & 39 \\
\hline 720 & ELE & 21 & 48 & 14 & 0 & 29 & 10 & 76 & 38 \\
\hline 765 & SR & 26 & 58 & 4 & 8 & 19 & 12 & 85 & 31 \\
\hline $823^{\mathrm{d}}$ & $\mathrm{CM}$ & 17 & 29 & 18 & 24 & 29 & 0 & 82 & 29 \\
\hline \multicolumn{3}{|c|}{$\begin{array}{l}\text { Kruskal-Wallis chi-square } \\
\quad(\alpha=0.05)\end{array}$} & 92.06 & 69.45 & 64.29 & 68.15 & 86.76 & 83.06 & 92.54 \\
\hline \multicolumn{3}{|c|}{$P$} & $<0.001$ & 0.023 & 0.058 & 0.031 & $<0.001$ & $<0.001$ & $<0.001$ \\
\hline
\end{tabular}


duced. Eventually the few living branches near the top can no longer support continued growth, and the tree dies.

$P$. sylvestris generally has been considered relatively susceptible to pine-pine gall rust (4), but in 25 years of research involving multiple provenances from the British Isles, France, Spain, Greece, and Turkey planted on sites ranging from former fertile farm lands to strip-mine spoil banks, incidence of infection rarely has exceeded $10 \%$, and mortality usually ranges from 3 to 5\% (4; W. Merrill, B. Kistler, L. Zang, and N. Wenner, unpublished data). In contrast, some Pinus spp. from the western United States are much more susceptible when planted in the East, including ponderosa $(5,9)$ and Jeffrey pines (1). Indeed, between 1943 and 1964 this pinepine gall rust killed nearly $100 \%$ of the $P$. jeffreyi plantations in the Stinchfield Forest in Michigan, and Baxter (1) stated that this fungus was "...more destructive to pines than has been observed for any rust on any host for over 60 years of plantation experiences..."

Such high incidence of infection and mortality has not been reported in the more arid western plains and mountains, probably due to lack of sufficient moisture during the infection period. Wave years of infection have been reported in the western United States (7) and Canada (8), and Peterson (7) related these to summer rains. Our studies showed that infection occurs during the early stages of shoot elongation, beginning as needles emerge from the fascicle sheath, and can be prevented by a single application of fungicide at that time (3). In the eastern United States, the normal spring weather during this period is characterized by frequent rains. In the mid-Atlantic states, high levels of infection have occurred every year from 1965 to 1996 , except during the severe drought of 1991, when no rains occurred from prior to budbreak during late May until early October (W. Merrill, B.
Kistler, L. Zang, and N. Wenner, unpublished data). Because the southern and southeastern United States have virtually the same spring weather patterns, we believe that the same levels of infection would occur there should this pathogen be introduced.

To identify the best ponderosa pine seed sources for reforestation plantings under conditions similar to those existing in central Pennsylvania, the relationship between tree survival after outplanting and incidence of infection was investigated for each provenance (Fig. 1). Seed sources in the upper right quadrant of Figure 1 had high rates of survival and low percentages of infection. Thus, the 1991 data suggest provenances $827,854,839,704$, and 838 were the most successful seed sources included in this study. Of these, only source 827 had less than $40 \%$ infected trees. Thus, none of these sources is suitable for reforestation use in any area of the eastern United States where this pathogen occurs.

Geographic ecotypes. There were no significant differences among ecotypes in the percentages of trees infected $(P=0.094)$ (Table 2, column 7). There were some similarities between this study and those of Merrill et al. (5) and Thomas et al. (9). All three studies showed a general trend of increasing infection among ecotypes from north to south, although the means of evaluating infection levels in the field varied from study to study. We found the percent-

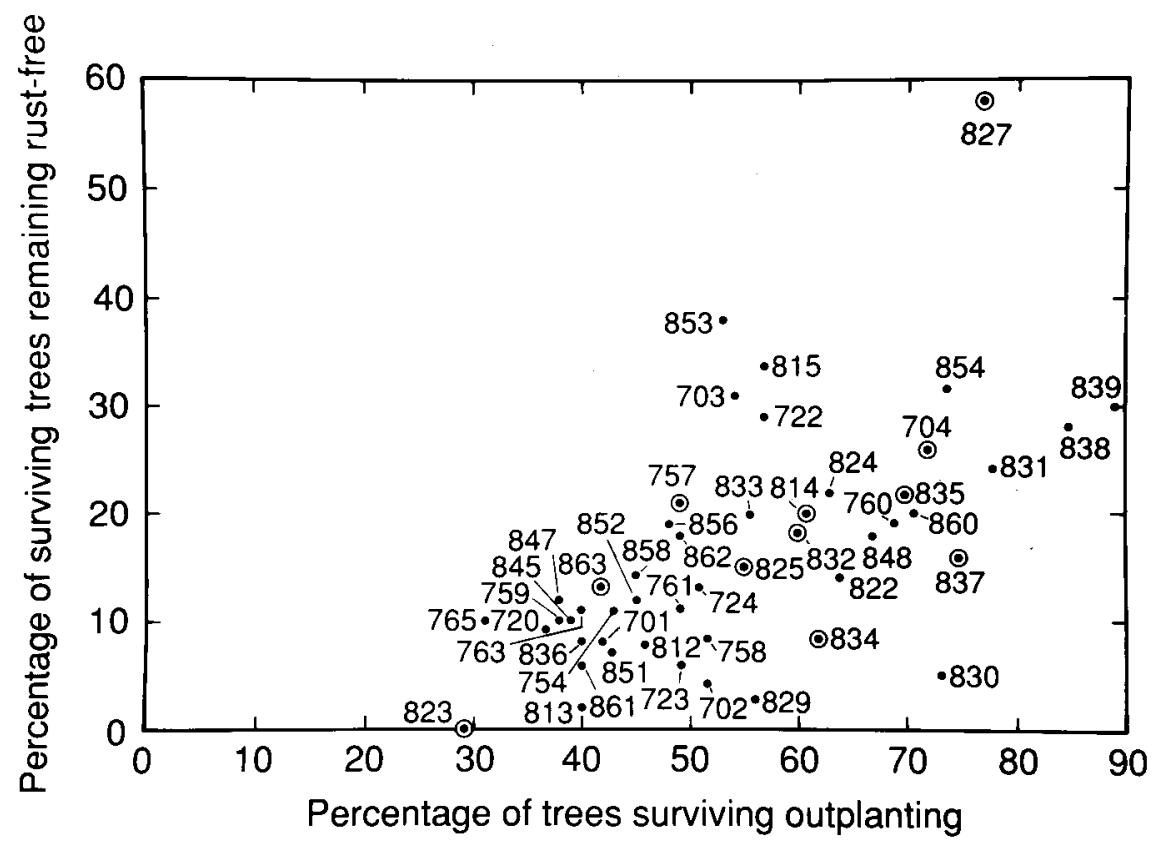

Fig. 1. Relationship between the percentages of the seedlings of 49 provenances of Pinus ponderosa that survived outplanting in central Pennsylvania and the percentage of those survivors that remain uninfected by Endocronartium harknessii. Data points enclosed in circles indicate provenances designated by Davidson (2) as "superior" for reforestation of strip-mine spoil banks in Pennsylvania.

Table 2. Percentages of the original 1969 planting of ponderosa pine trees in central Pennsylvania, by ecotype, that were missing in 1991, trees that survived outplanting and in 1991 were dead due to various causes, and trees that survived outplanting and in 1991 were alive, infected or uninfected by Endocronartium harknessii

\begin{tabular}{|c|c|c|c|c|c|c|c|c|}
\hline \multirow[b]{2}{*}{ Ecotype } & \multirow{2}{*}{$\begin{array}{c}\% \text { Original } \\
\text { planting mis- } \\
\text { sing in } 1991 \\
\text { (Col. 1) }\end{array}$} & \multicolumn{3}{|c|}{$\%$ Dead in $1991^{a}$} & \multicolumn{2}{|c|}{$\%$ Alive in $1991^{\mathrm{a}}$} & \multicolumn{2}{|c|}{$\%$ Surviving trees } \\
\hline & & $\begin{array}{l}\text { Due to rust } \\
\text { (Col. 2) }\end{array}$ & $\begin{array}{l}\text { Uninfected } \\
\text { (Col. 3) }\end{array}$ & $\begin{array}{l}\text { Indeterminate } \\
\quad \text { (Col. 4) }\end{array}$ & $\begin{array}{c}\text { Infected } \\
\text { (Col. 5) }\end{array}$ & $\begin{array}{l}\text { Uninfected } \\
\text { (Col. 6) }\end{array}$ & $\begin{array}{l}\text { Infected in } 1991^{b} \\
\quad(\text { Col. } 7)\end{array}$ & $\begin{array}{l}\text { Alive in } 1991^{\circ} \\
\quad(\text { Col. 8) }\end{array}$ \\
\hline Central Rockies & 32 & 33 & 5 & 5 & 43 & 14 & 81 & 50 \\
\hline Central Montana & 31 & 24 & 11 & 10 & 38 & 12 & 71 & 50 \\
\hline East-low elevation & 45 & 39 & 12 & 2 & 31 & 18 & 71 & 48 \\
\hline Transition & 43 & 38 & 9 & 10 & 32 & 11 & 79 & 43 \\
\hline Black Hills & 35 & 26 & 5 & 2 & 48 & 20 & 75 & 67 \\
\hline High plains & 42 & 31 & 6 & 5 & 36 & 21 & 73 & 57 \\
\hline Colorado plains & 51 & 46 & 4 & 1 & 38 & 12 & 84 & 49 \\
\hline Southern Rockies & 51 & 46 & 7 & 6 & 27 & 14 & 79 & 41 \\
\hline $\begin{array}{l}\text { Kruskal-Wallis } \\
\text { chi square }\end{array}$ & 19.25 & 20.65 & 31.53 & 16.81 & 16.07 & 12.29 & 12.20 & 22.77 \\
\hline$P$ & 0.007 & 0.004 & $<0.001$ & $<0.001$ & 0.024 & 0.091 & 0.094 & 0.002 \\
\hline
\end{tabular}

${ }^{a}$ Because of rounding off, percents in columns 2 through 6 may not add up to 100.

b Sum of columns 2, 4, and 5 .

${ }^{\mathrm{c}}$ Sum of columns 5 and 6. 
age of infected trees in central Montana = east-low elevation < high plains < Black Hills $<$ southern Rockies = transition $<$ central Rockies < Colorado plains. The KruskalWallis multiple comparison test indicated a significant difference $(\alpha=0.05)$ in average percentages of infected trees between sources in the Colorado plains and four other areas: central Montana, east-low elevation, Black Hills, and high plains. There were no significant differences among ecotypes in the percentages of trees that were alive and uninfected $(P=0.091)$ (Table 2, column 6).

Forty percent of the original seedlings in the plantation were missing. This agrees closely with Davidson's (2) estimated survival of $61 \%$ of original seedlings in 1971, 2 years after planting. Seedlings described by Davidson (2) as not surviving outplanting were categorized in 1991 as missing trees. All other trees were accounted for in one of the other seven categories. The percentages of missing trees varied among the eight ecotypes, but no geographic trend was apparent.

There were significant differences among the eight ecotypes, both in mortality due to rust $(P=0.004)$ and mortality unrelated to rust $(P<0.001)$ (Table 2 , columns 2 and 3 , respectively). The Colorado plains and southern Rockies sources had the highest average percentage of trees dead due to rust $(46 \%)$ (Table 2, column 2). Of the seedlings from provenances originating in east-low elevation and central Montana, 12 and $11 \%$, respectively, succumbed to environmental factors and pathogens other than E. harknessii (Table 2, column 3). However, the central Montana ecotype ranked low both in the percentages of trees infected with rust $(71 \%)$ and trees succumbing to rust (24\%) (Table 2, columns 7 and 2, respectively). There may have been more seedlings from this region available to be killed by other pathogens, or trees from central Montana sources may have higher resistance to pine-pine gall rust but lower resistance to other as yet unidentified disease agent(s) or pest(s).

The percentages of trees that were alive in 1991 differed significantly $(P=0.002)$
(Table 2, column 8). Trees from the Black Hills $(67 \%)$ and high plains $(50 \%)$ had more living trees in 1991 than did other ecotypes. In terms of percentage of trees infected with pine-pine gall rust, these ecotypes were about average (Table 2, column 7). Provenances from the southern Rockies had the lowest percentage of living trees (41\%) (Table 2, column 8).

Block effects. Six experimental blocks were arranged from west (block 1) to east (block 6) to investigate the possible effect of prevailing westerly winds on the spread of gall rust inoculum through the plantation. To facilitate analysis, data were combined for blocks 1 and 2, 3 and 4, and 5 and 6 . Analysis of the proportion of rustinfected trees per paired blocks indicated a block effect of borderline significance $(P=$ 0.055). The Kruskal-Wallis chi-square test indicated a difference $(P=0.04)$ between block pairings 1 and 2 (74\% infected) and 5 and 6 (80\% infected). This agrees with Merrill et al. (5) who reported increasing levels of infection from west to east.

Concluding comments. Although no provenance was free of infection by $E$. harknessii, some seed sources may be cautiously recommended over others. In so doing, more than one variable must be considered. For example, provenance 839 had the highest survival rate $(88 \%)$ among all seed sources. However, $70 \%$ of trees from this seed source were infected with pinepine gall rust. The smallest percentage of pine-pine gall rust infection 22 years after planting $(29 \%)$ was in provenance 827 . Further, a relatively high percentage $(79 \%)$ of trees from this seed source were still alive and a relatively small percentage had died from rust infection (10\%). Any recommendations as to seed source for reforestation purposes should be framed by this type of information.

Conversely, most seed sources contained trees that remained uninfected even when their branches were entwined with branches of galled trees. We have noted the same phenomenon within numerous provenances of $P$. sylvestris (4). Thus, there are trees in all provenances that could be used in breed- ing trials.

It is apparent that $P$. ponderosa seedlings from sources in the high plains and Black Hills have the greatest chances of surviving on reclamation sites and under conditions similar to those investigated here. Although they were below average in terms of mortality due to rust, they ranked near average in terms of percentage of trees infected.

The results of this study indicate that the initial predictions about the performance of seedlings in this outplanting (2) were extremely tenuous. The dangers in recommending seed sources for reforestation projects based only on height and survival 6 years after outplanting are obvious. If reforestation is to be considered successful, the evaluation of disease and pest resistance and long-term tree survival within the ecosystem are essential.

\section{LITERATURE CITED}

1. Baxter, D. V. 1967. Disease in Forest Plantations: Thief of Time. Cranbrook Inst. Sci. Bull. 151.

2. Davidson, W. H. 1977. Performance of ponderosa pine on bituminous mine spoils in Pennsylvania. U.S. Dep. Agric. For. Serv. Res. Pap. NE-358.

3. Merrill, W., and Kistler, B. R. 1976. Phenology and control of Endocronartium harknessii in Pennsylvania. Phytopathology 66:1246-1248.

4. Merrill, W., and Wenner, N. 1985. Pine-pine gall rust: History, distribution, and spread in the northeastern United States. Pages 271-283 in: Proc. Rusts Hard Pines Work. Party Conf., J. Barrows-Broadus and H. R. Powers, eds. University of Georgia, Athens.

5. Merrill, W., Wenner, N., and Towers, B. 1986 Resistance of Pinus ponderosa to Endocronartium harknessii in Pennsylvania. Plant Dis. 70:317-320.

6. Peterson, G. W. 1973. Dispersal of aeciospores of Peridermium harknessii in central Nebraska. Phytopathology 63:170-172.

7. Peterson, R. S. 1959. Pine gall rust in the Rocky Mountains. Diss. Abstr. 20(5):1557.

8. Powell, J. M., and Hiratsuka, Y. 1973. Serious damage caused by stalactiforme blister rust and western gall rust to a lodgepole pine plantation in central Alberta. Can. Plant Dis. Surv. 53:6771.

9. Thomas, C. S., Hart, J. H., and Cress, C. E. 1984. Severity of Endocronartium harknessii in two provenance stands of Pinus ponderosa in Michigan. Plant Dis. 68:681-683. 